\title{
Characterization of NKT-cell Hybridomas Expressing Invariant T-cell Antigen Receptors
}

\author{
Dashtsoodol Nyambayar ${ }^{1,2)}$, Kazuya Iwabuchi' ${ }^{11}$, Emma Hedlund ${ }^{1,3)}$, Satoko Murakawa ${ }^{1)}$, \\ Keiko Shirai ${ }^{11}$, Chikako Iwabuchi'1), Yujiroh Kon ${ }^{1)}$, Yusei Miyazaki ${ }^{11}$, \\ Yoshiki Yanagawa'), and Kazunori Onoé1)
}

Two natural killer T (NKT)-cell hybridomas were established by fusing sorted NKT cells with BW1100 thymoma cells. The first hybridoma line, $1 \mathrm{~B} 6$, was $\mathrm{CD}^{+} 8^{-}$, whereas the second one, $2 \mathrm{E} 10$, was $\mathrm{CD} 4^{\text {low }} 8^{-}$. Initial characterizations revealed that both cell lines expressed an invariant $\mathrm{T}$ cell antigen receptor, which could be readily detected with $a$-galactosylceramide-loaded CD1d : Ig fusion protein ( $a$-GalCer/CD1d). Sequence analyses of the $a$ and $\beta$ chains of the T cell receptor V genes revealed that $1 \mathrm{~B} 6$ and $2 \mathrm{E} 10$ cells expressed $\mathrm{V}_{a} 14 \mathrm{~J}_{a} 18 / \mathrm{V} \beta 8.2 \mathrm{D} \beta 2 \mathrm{~J} \beta 2.7$ and $\mathrm{V}_{a} 14 \mathrm{~J}_{a} 18 / \mathrm{V} \beta 8.1 \mathrm{D} \beta 1 \mathrm{~J} \beta 1.1$, respectively. When these hybridoma cells were stimulated with immobilized anti-CD3 monoclonal antibodies, $a$-GalCer/CD1d, or $a$-GalCer in the presence of antigen-presenting cells, they produced IL-4 and IFN- $\gamma$. The expression levels of CD69, CD154, and CD178 were concomitantly up-regulated on both hybridomas upon stimulation. Because it is difficult to isolate a sufficient number of NKT cells, these hybridomas should provide useful platforms to study a variety of functions of NKT cells. $〔 \mathrm{~J}$ Clin Exp Hematopathol 47 (1) : 1-8, 2007]

Keywords: NKT-cell, Hybridoma, Invariant TCR, IL-4, IFN- $\gamma$.

\section{INTRODUCTION}

NKT cells constitute a unique subset of $\mathrm{T}$ lymphocytes that recognize non-peptide antigens such as glycosphingolipids and phospholipids in the context of the non-classical class I major histocompatibility complex (MHC) molecule CD1 $\mathrm{d}^{1,2}$. In mice, a major subpopulation of NKT cells expresses the $\mathrm{V}_{a} 14 \mathrm{~J}_{a} 18$ invariant $a$ chain, which is preferentially associated with the $\mathrm{V} \beta 8, \mathrm{~V} \beta 7$, or $\mathrm{V} \beta 2$ chains of the $\mathrm{T}$ cell antigen receptor (TCR). To date, NKT cells have been reported to be active in various host responses against pathogenic microbes and tumors, and in inflammatory and autoimmune diseases ${ }^{3,4}$. Thus, examination of the ligand-based

Received : Apr 17, 2006

Revised : Jun 27, 2006

Accepted: Aug 1, 2006

"Division of Immunobiology, Research Section of Pathophysiology, Institute for Genetic Medicine, Hokkaido University, Sapporo, Japan.

${ }^{22}$ Present address : RIKEN Research Center for Allergy and Immunology, Yokohama, Japan

${ }^{33}$ Present address : Lund University School of Medicine, Lund, Sweden

Address correspondence and reprint request to Kazunori Onoé or Kazuya Iwabuchi Division of Immunobiology, Research Section of Pathophysiology, Institute for Genetic Medicine, Hokkaido University, Kita-15, Nishi-7, Kita-Ku, Sapporo 060- 0815, Japan.

E-mail : kazunori@igm.hokudai.ac.jp (KO) ; akimari@igm.hokudai.ac.jp (KI). modulation of NKT cells has been expected to provide new therapeutic targets for these diseases ${ }^{5,6}$.

The paucity of available NKT cells, however, has proved to be an obstacle during in vitro functional studies of these cells. Thus, the utilization of NKT-cell hybridomas may offer a convenient platform to examine specific functions of NKT cells and to screen arrays of natural products or synthetic compounds for potential therapeutic agents. Thus far, a number of NKT-cell hybridomas have been established in several laboratories $^{7-9}$. In the present study, two NKT-cell hybridomas were established and the characteristics of these cell lines were examined.

\section{MATERIALS AND METHODS}

\section{Cells}

A fusion partner, the BW1100.129.237 cell line (TCR $a^{-}$ $\left.\beta^{-}\right)^{10}$, was kindly provided by Dr. Willi Born (Department of Immunology, National Jewish Medical and Research Center, Denver, CO). BW1100 cells and established hybridomas were cultured in RPMI-1640 (Sigma Chemical Co., St. Louis, MO) supplemented with $10 \%$ fetal calf serum (FCS; Invitrogen Corp., Carlsbad, CA), benzylpenicillin potassium (100 U/ml ; Meiji Seika Kaisha Ltd., Tokyo, Japan), strepto- 
mycin sulfate $(100 \mu \mathrm{g} / \mathrm{ml}$; Meiji Seika), and $\beta$ mercaptoethanol $\left(1 \times 10^{-5} \mathrm{M}\right.$; LifeTechnologies, Grand Island, NY).

\section{Preparation and activation of NKT cells}

NKT cells were purified from the thymi of C57BL/ 6 mice purchased from Japan SLC (Hamamatsu, Japan) as previously described ${ }^{11}$. In brief, thymocytes were incubated with anti-CD24 monoclonal antibodies (mAbs) (J11d) and anti-CD8 mAbs (53.6.7) followed by an incubation with goat anti-rat immunoglobulin (Ig) G microbeads (Miltenyi Biotec $\mathrm{GmbH}$, Bergisch Gladbach, Germany). Then, the CD24CD8 $8^{-}$thymocytes that passed through an LS column (Miltenyi) were labeled with phycoerythrin (PE)-conjugated anti-NK1.1 (BD Biosciences Pharmingen, San Diego, CA) and fluorescein isothiocyanate (FITC)-conjugated anti-TCR $\beta$ antibodies (BD Biosciences). After the NK1.1 $1^{+} \mathrm{TCR} \beta^{+}$cellular population was isolated as NKT cells with a FACS (fluorescence-activated cell sorter) Vantage SE (BD Biosciences Immunocytometry Systems, Mountain View, CA), the sorted cells were cultured overnight in medium containing recombinant human (rh)IL-2 (300 U/ml; kindly provided by Takeda Chemical Industries, Osaka, Japan). Then, the NKT cells were activated with $a$-GalCer (100 ng/ml ; kindly provided by Kirin Brewery Company, Takasaki, Japan) in the presence of irradiated (30 Gy) spleno-

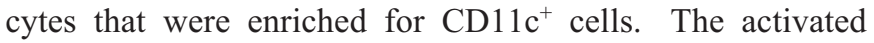
NKT cells were expanded in the presence of rhIL-2 (300 $\mathrm{U} / \mathrm{ml})^{12}$ and later employed in the cell fusion experiments.

\section{Establishment of the hybridoma lines}

A standard protocol for establishing B-cell hybridomas ${ }^{13}$ was employed for the fusion of the NKT cells and the BW1100 cells. In brief, the sorted NKT cells and the BW1100 cells were washed three times with RPMI-1640 medium without FCS and pelleted. Polyethylene glycol 1500 (Roche Diagnostics, Ingelheim, Germany) was added to the resulting pellets dropwise followed by a dilution with RPMI1640. Then, the cells were spun down and resuspended in HAT medium (RPMI-1640 containing hypoxanthine, aminopterin, and thymidine; Roche Diagnostics) for culture. Colonies were picked and transferred to HT medium (RPMI1640 containing hypoxanthine and thymidine; Roche Diagnostics) and then to RPMI-1640 containing 10\% FCS for further analysis.

\section{Antibodies and flow cytometry}

Hybridoma cells were first incubated with 2.4G2 mAbs (anti-Fc $\gamma \mathrm{R}$ ) to block non-specific binding, and then labeled with a combination of the following $\mathrm{mAb}$ conjugates: bio- tinylated (biotin)-anti-V $\beta 8.1 / 8.2$ (F23.1, mouse $\mathrm{IgG}_{2 \mathrm{a}}$ isotype); FITC-anti-TCR $\beta$ (H57-597, hamster $\mathrm{IgG}_{2}$ isotype) ; FITC-anti-CD1d (1B1, rat $\operatorname{IgG}_{2 b}$ isotype), FITC-antiCD49b (DX5, rat IgM isotype); FITC-anti-CD69 (H1.2F3, hamster $\mathrm{IgG}_{1}$ isotype); FITC-anti-CD95 (Jo2); PE-anti-NKT/NK cell antigen (U5A2-13, rat $\operatorname{IgG}_{2 \mathrm{a}}$ isotype); PE-antiCD154 (MR1, hamster $\mathrm{IgG}_{3}$ isotype); PE-anti-CD178 (MFL3); and allophycocyanin (APC)-CD161 (PK136, mouse $\mathrm{IgG}_{2 \mathrm{a}}$ isotype). Preparation of $a$-GalCer/CD1d was performed according to the manufacturer's instructions by incubating CD1d: Ig fusion protein with $a$-GalCer at $37^{\circ} \mathrm{C}$ overnight. For the detection of invariant TCR (iTCR), cells were incubated with $a$-GalCer/CD1d for $60 \mathrm{~min}$ at $4{ }^{\circ} \mathrm{C}$ followed by incubation with PE-anti-mouse $\operatorname{IgG}_{1}$. All reagents for flow cytometry were purchased from BD Biosciences Pharmingen. Propidium iodide-positive (Sigma) cells were electronically gated out from the analysis, and cells were analyzed using a FACScalibur flow cytometer (BD Biosciences Immunocytometry Systems) with CellQuest software (BD Biosciences).

\section{Sequencing the iTCRs from the hybridomas}

Total RNA was extracted from 1B6 and 2E10 cells using the acid guanidium thiocyanate- phenol- chloroform method ${ }^{14}$. Reverse transcription was performed as previously described $^{11}$. The invariant $\mathrm{V}_{a}$ chain was amplified from complemantary DNA using the polymerase chain reaction with the $\mathrm{V}_{a} 14$ (5'-CAC/AGC/CAC/CCT/GCT/GGA/T-3') and $\mathrm{J}_{a} 18$ (5'-CCA/AAA/TGC/AGC/CTC/CCT/AA-3') primer pair. The $\mathrm{V} \beta$ chain was amplified with the primer pairs of either V $\beta 8.1$ with an EcoRI site (5'-CTC/ GAA/ TTC/ ATG/ GGC/ TCC/AGA/CTC/TTC/ TT-3') or $\mathrm{V} \beta 8.2$ with an EcoRI site (5'-CTC/ GAA/ TTC/ TAA/ CAC/ $\left.\mathrm{TGC} / \mathrm{CTT} / \mathrm{CCC} / \mathrm{TGA}-3^{\prime}\right)$ and a common $\mathrm{C} \beta$ primer with a BamHI site ( $5^{\prime}-C T C / G G A / T C C /$ TTT/ TGT/ TTG/ TTT/ GCA/AT-3' $)^{15}$. Each amplified band was directly sequenced with the dye terminator method by Hokkaido System Science Co. (Sapporo, Japan). Genomic DNA sequences for the assignment of rearranged TCR genes were retrieved from National Center for Biotechnology Information (NCBI ; www.ncbi.nlm.nih.gov/).

\section{Activation of the hybridomas}

Each well of a 24-well plate was coated with

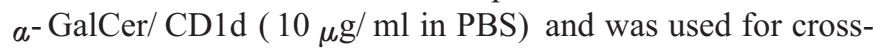
linking the NKT-cell hybridomas in vitro. The hybridomas were harvested after 12-hr incubations and used for FACS analysis as described above. Supernatants were also collected for the quantification of the production of IL-4 and IFN- $\gamma$. In some experiments, hybridomas were cultured with the $\mathrm{BC} 1$ murine dendritic cell line ${ }^{16}$ or a rat basophilic leukemia cell 
line transfected with murine CD1d1, RBL-CD1d ${ }^{11}$ (kindly provided by Dr. Albert Bendelac, University of Chicago), as antigen-presenting cells in the presence of $a$-GalCer.

\section{Quantification of cytokine levels}

The levels of IFN- $\gamma$ and IL- 4 in the culture supernatants were quantified with an OptEIA enzyme- linked immunosorbent assay (ELISA) kit (BD Biosciences) according to the manufacturer's protocol ${ }^{17}$. A cytometric bead array (BD Biosciences) was also employed for the quantification of the cytokine levels in the supernatant using the manufacturer's protocol.

\section{RESULTS AND DISCUSSION}

\section{Characterization of the surface markers of the NKT-cell hybridomas}

Two hybridoma cell lines, 1B6 and 2E10, were established and characterized in the present study. First, we examined the expression of iTCR and several surface markers. Because the source NKT cells for fusion were derived from $a^{-}$ GalCer/CD1d-expressing cells, it was not surprising that both

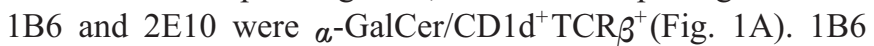
cells uniformly expressed CD4 at a high level, whereas the expression of CD4 in 2E10 cells was either undetectable or observed at a low level (Fig. 1A).

Next, typical molecular markers of NKT cells were examined. It was found that both 1B6 and 2E10 did not express a detectable level of NK1.1 (CD161c) or DX5 (CD49b) (Fig. 1B). It has been reported that the expression of NK1.1 is lost during activation of the cells ${ }^{18}$. Thus, it appeared that the source NKT cells collected from the thymus stopped expressing NK1.1 during activation with $a$-GalCer and expansion with rhIL-2 prior to fusion with the BW1100 cells. Because thymic NK $1.1^{+} \mathrm{TCR} \beta^{-}$cells, but not NK $1.1^{+} \mathrm{TCR} \beta^{+}$cells, express DX $5^{11}$, it is likely that the resultant hybridoma cells are indeed $\mathrm{DX}^{-}$. 1B6 cells were weakly labeled by the panNK/T marker U5A2-13, whereas 2E10 cells were not labeled with this antibody. U5A2-13 antibodies recognize a conformational epitope of intercellular adhesion molecule- ${ }^{19}$. Both hybridoma cell lines demonstrated enhanced expression of the U5A2- 13 epitope after anti-CD3 crosslinking (data not shown). Additionally, both hybridoma cell lines expressed the restriction molecule CD1d (Fig. 1B).

\section{Morphology of the NKT-cell hybridomas}

Forward light scatter (FSC) analysis demonstrated that the 2E10 cells were larger than the 1B6 cells (Fig. 1C). When the cells were examined under a light microscope, both the 1B6 and 2E10 cells had a T cell blast-like morphology, similar to the original NKT cells (Fig. 1D). Upon activation with immobilized anti-CD3 mAbs, a significant extension of the uropod-like structures was observed (Fig. 1D). These findings demonstrate that both hybridoma cell lines retained the morphological traits of NKT cells even after fusion with the thymomas.

\section{Sequences of TCR genes in the NKT-cell hybridomas}

Next, we sequenced the $\mathrm{V}_{a}$ and $\mathrm{V}_{\beta}$ TCR genes expressed by the $1 \mathrm{~B} 6$ and $2 \mathrm{E} 10$ cells. Both cell lines expressed invariant $\mathrm{V}_{a}$ chains with identical amino-acid sequences, including a Gly residue in the complementarity-determining region (CDR) 3 (Fig. 2A). 2E10 cells had a $\mathrm{G}$ as non-coding (N) sequence, whereas 1B6 cells had no $\mathrm{N}$ nucleotide but did have an $\mathrm{A}$ after $\mathrm{J}_{a} 18$; both of these sequences result in a codon for a Gly residue at a position that typically is conserved in the $\mathrm{V}_{\boldsymbol{a}}$ chain of $\mathrm{iTCR}^{7,20}$.

As expected, 1B6 and 2E10 cells were labeled with anti$\mathrm{V} \beta 8.1 / 8.2 \mathrm{mAbs}$ (F23.1) (data not shown). PCRs with the $\mathrm{C} \beta$ common primer and either the $\mathrm{V} \beta 8.1$ primer or $\mathrm{V} \beta 8.2$ primer demonstrated that the 1B6 and 2E10 cell lines carried V $\beta 8.2$ and $\mathrm{V} \beta 8.1$, respectively (data not shown). Further analyses revealed that $1 \mathrm{~B} 6$ carried $\mathrm{V} \beta 8.2 \mathrm{D} \beta 2 \mathrm{~J} \beta 2.7$, whereas $2 \mathrm{E} 10$ carried $\mathrm{V} \beta 8.1 \mathrm{D} \beta 1 \mathrm{~J} \beta 1.1$ with $\mathrm{N}$ nucleotides as shown in Fig. $2 \mathrm{~B}$. 1B6 cells had a TGA sequence as $\mathrm{N}$ nucleotides that resulted in an Asp residue between $\mathrm{D} \beta 2$ and $\mathrm{J} \beta 2$.7. On the other hand, $2 \mathrm{E} 10$ cells had a $\mathrm{C}$ as an $\mathrm{N}$ nucleotide after joining $\mathrm{V} \beta 8.1$ with $\mathrm{D} \beta 1$; changing the $\mathrm{T}$ to $\mathrm{C}$, however, did not change the corresponding Ser residue. As previously reported with the variety of $\mathrm{V} \beta 8$ chains expressed by iNKT cells ${ }^{7}$, the two hybridoma cell lines in this study employed different VDJ sets and expressed differently sized variants of CDR3; the 2E10 cells expressed a shorter CDR3 than the 1B6 cells.

\section{Surface molecules on the activated NKT-cell hybridomas}

We then examined the surface markers that were expressed following activation through the TCR/ CD3 complex. Unstimulated 1B6 and 2E10 cells were negative for CD69, CD154, and CD178. These markers were markedly upregulated $12 \mathrm{hr}$ after iTCRs were crosslinked with immobilized $a^{-}$ GalCer/CD1d (Fig. 3A, B). Of note, these hybridomas, which were weakly positive for CD95, expressed substantial levels of CD95 upon stimulation (Fig. 3A, B). These results clearly indicate that the activation markers were expressed on the hybridoma cells only after stimulation, and suggest that these hybridomas retained characteristics that were typical of normal unstimulated NKT cells in the absence of stimulation. The expression levels of CD154 and CD178 were reduced to the background levels when the cells were stimulated for 12 $\mathrm{hr}$ and then cultured for $24 \mathrm{hr}$ without any stimulation. By contrast, the 1B6 and 2E10 cells were still $\mathrm{CD} 69^{+}$under the 
A.

$1 B 6$

2E10

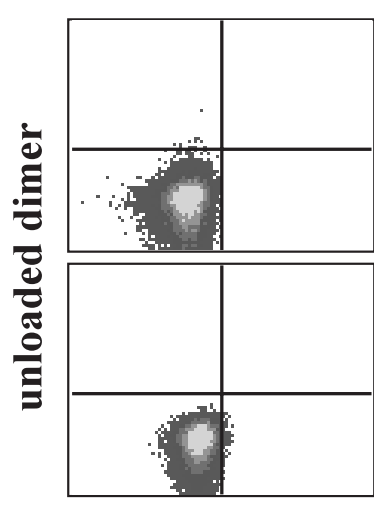

control

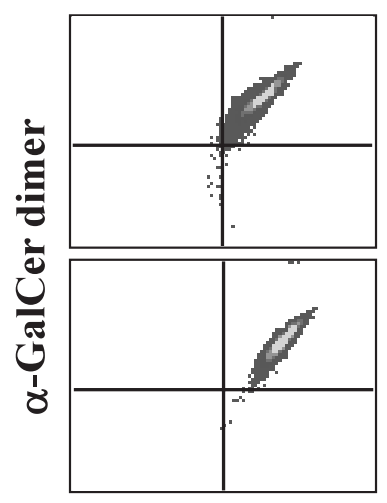

TCR $\beta$
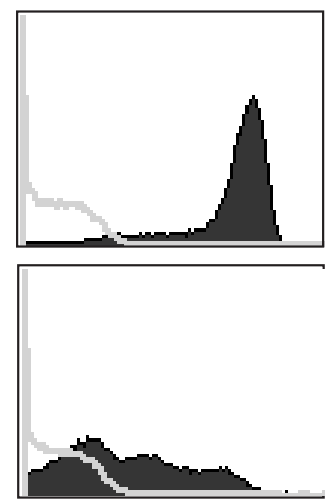

CD4

B.
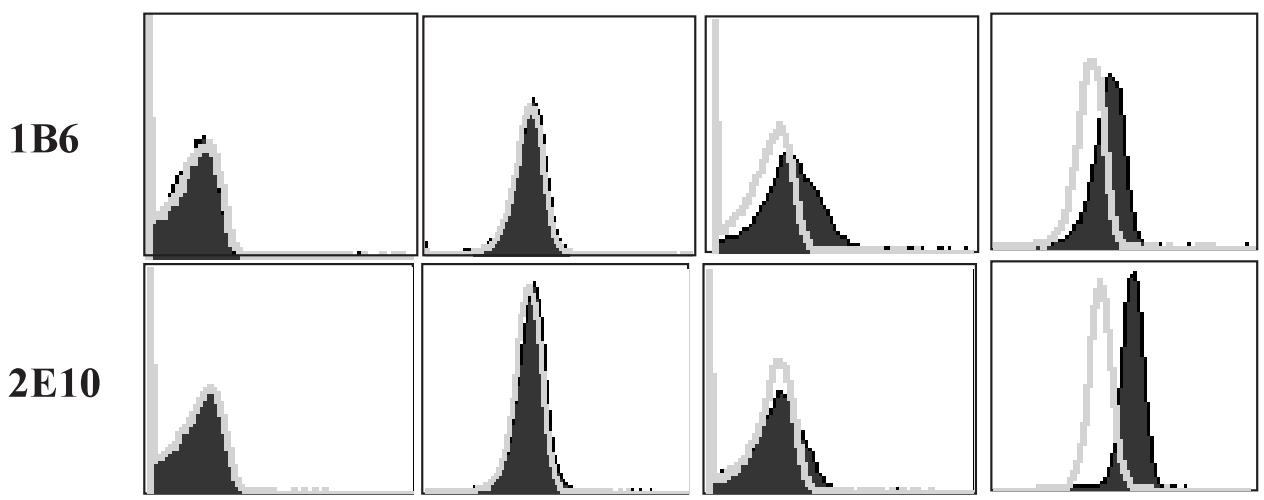

NK1.1

DX5

U5A2-13

CD1d

C.

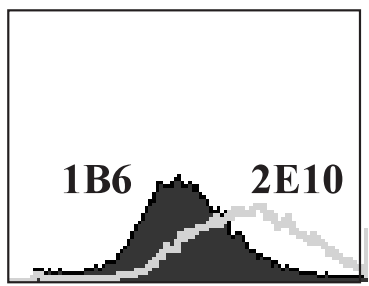

FSC
D.

resting

anti-CD3cl

$1 B 6$
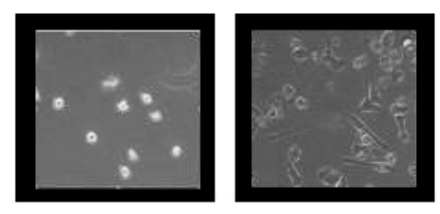

2810
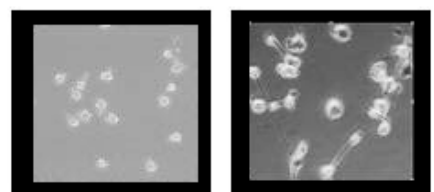

Fig. 1. Expression levels of iTCR, CD4 and NK markers on $1 B 6$ and 2E10 cells, and the morphologies of these cells. A. Expression levels of unloaded CD1d versus isotype controls (left

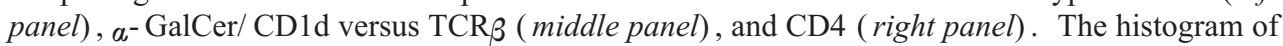
an isotype control ( rat IgG2b) for CD4 is overlaid as thin lines in the right panels. B. Histograms for NK markers : NK1.1 (CD161c), DX5 (CD49b), and U5A2-13 (pan-NK/T), and CD1d. The histograms (filled) are overlaid with their isotype controls (thin lines). C. Forward light scatter data for 1B6 (filled histogram) and 2E10 (thin line) cells. D. Morphologies of 1B6 and 2E10 cells. Hybridomas were observed under a phase contrast microscope. Resting cells (left panel) and cells stimulated with immobilized anti-CD3 mAbs (right panel) are shown. Original magnification $\times 200$. 


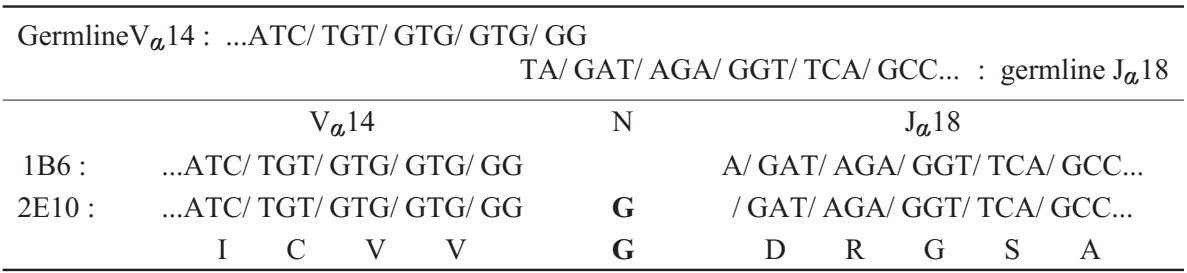

B.

V 88.2 : ...TGT/ GCC/ AGC/ GGT/ GAT/ G

$\mathrm{D} \beta 2: G / \mathrm{GGA} / \mathrm{CTG} / \mathrm{GG} G G G G C$

J $\beta 2.7: C T C \mathrm{C} / \mathrm{TAT} / \mathrm{GAA} / \mathrm{CAG} / \mathrm{TAC} / \mathrm{TTC} \ldots$

\begin{tabular}{|c|c|c|c|c|c|c|c|c|c|c|c|c|c|c|}
\hline \multirow{3}{*}{ 1B6: } & \multicolumn{5}{|c|}{$\mathrm{V} \beta 8.2$} & \multicolumn{3}{|c|}{$\mathrm{D} \beta 2$} & $\mathrm{~N}$ & \multicolumn{5}{|c|}{$\mathrm{J}_{\beta} 2.7$} \\
\hline & \multicolumn{5}{|c|}{...TGT/ GCC/ AGC/ GGT/ GAT/ } & \multicolumn{3}{|c|}{ GGA/CTG/GG } & $\mathbf{T} / \mathbf{G A}$ & $\mathrm{C} / \mathrm{TA}$ & GA & $\mathrm{CA}$ & $\Gamma \mathrm{AC}$ & TC... \\
\hline & $\mathrm{C}$ & A & $\mathrm{S}$ & $\mathrm{G}$ & $\mathrm{D}$ & $\mathrm{G}$ & $\mathrm{L}$ & $\mathrm{G}$ & D & Y & $\mathrm{E}$ & $\mathrm{Q}$ & $\mathrm{Y}$ & $\mathrm{F}$ \\
\hline
\end{tabular}

V $\beta 8.1: \ldots \mathrm{TGT} / \mathrm{GCC} / \mathrm{AGC} / \mathrm{AGT} / \mathrm{GAT} / G$

$\mathrm{D} \beta 1: G G G / \mathrm{ACA} / \mathrm{GG} G G G C$

J $\beta 1.1: C A A A C /$ ACA/ GAA/ GTC/ TTC/ TTT...

\begin{tabular}{|c|c|c|c|c|c|c|c|c|c|c|c|}
\hline \multirow{3}{*}{ 2E10: } & \multicolumn{4}{|c|}{$\mathrm{V}_{\beta} 8.1$} & $\mathrm{~N}$ & $\mathrm{D} \beta 1$ & \multicolumn{5}{|c|}{$\mathrm{J}_{\beta} 1.1$} \\
\hline & ...TGT & $\mathrm{CC}$ & $\mathrm{GC}$ & AG & $\mathrm{Cl}$ & $\mathrm{ACA} / \mathrm{GG}$ & $\mathrm{C} / \mathrm{AC}$ & GA & G1 & TT & ГТТ... \\
\hline & $\mathrm{C}$ & A & $\mathrm{S}$ & $\mathrm{S}$ & $\mathbf{T}$ & $\mathrm{G}$ & $\mathrm{T}$ & E & $\mathrm{V}$ & $\mathrm{F}$ & $\mathrm{F}$ \\
\hline
\end{tabular}

Fig. 2. Sequence analyses of the $\mathrm{V}_{a}$ and $\mathrm{V}_{\beta}$ chains of the iTCRs in the NKT-cell hybridomas. A. Nucleotide sequences of the rearranged iTCR $\mathrm{V}_{a}$ chains in the $1 \mathrm{~B} 6$ and $2 \mathrm{E} 10$ cell lines and the deduced amino- acid sequences. Germline $\mathrm{V}_{a}$ and $\mathrm{J}_{a} 18$ sequences are also aligned to compare the rearranged sequences. $T$ (italicized) in the 5 ' end of $\mathrm{J}_{a} 18$ was excised in the $1 \mathrm{~B} 6$ cells and $T A$ in $2 \mathrm{E} 10$. The $\mathrm{N}$ nucleotide is shown in bold font. B. Nucleotide sequences of the rearranged $\mathrm{V} \beta$ chains in the $1 \mathrm{~B} 6$ and $2 \mathrm{E} 10$ cell lines and the deduced amino- acid sequences. Germline V $\beta 8.2, \mathrm{D} \beta 2$, and $\mathrm{J} \beta 2.7$ sequences for $1 \mathrm{~B} 6$, and $\mathrm{V} \beta 8.1, \mathrm{D} \beta 1$, and $\mathrm{J} \beta 1.1$ sequences for $2 \mathrm{E} 10$ (italicized bases are excised on joining) are also aligned to compare the rearranged sequences. $\mathrm{N}$ nucleotides are shown in bold font. The amino-acid residue that is coded for due to the N-nucleotide addition is also shown in bold font.

A. 1 B6

resting

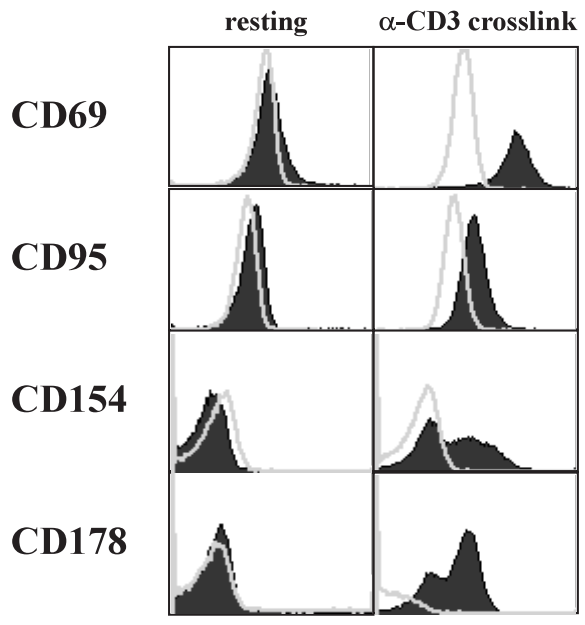

B. 2E10

resting $\quad \alpha$-CD3 crosslink

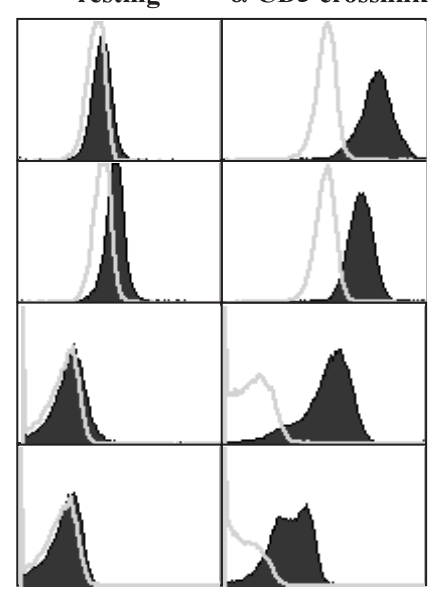

Fig. 3. Expressions of activation markers on NKT-cell hybridomas before and after activation. A. Expression levels of CD69, CD95 (Fas), CD154 (CD40L), and CD178 (FasL) on 1B6 cells before (resting) and after activation (anti-CD3 crosslinking) . B. Expression levels of CD69, CD95, CD154, and CD178 on 2E10 cells before (resting) and after activation (anti-CD3 crosslinking). In (A) and (B), the histogram for each $\mathrm{mAb}$ has been filled in and the respective isotype control histogram is shown as a thin line. 
same conditions (data not shown). Nevertheless, the reversible upregulation of these surface molecules indicated that these hybridoma cells were immunologically regulated, which will be important when these cells are used to screen reagents for activities that inhibit NKT-cell activation.

\section{Cytokine production by the NKT-cell hybridomas}

After crosslinking with $a$-GalCer/CD1d or anti-CD3
$\mathrm{mAbs}$, these hybridomas also produced significant levels of IFN- $\gamma$ and IL-4 that were similar to those produced in normal NKT cells. When 1B6 hybridoma cells were stimulated with immobilized anti-CD3 mAbs, IL-4 was detected in the supernatant after $6 \mathrm{hr}$ of culture, whereas IFN- $\gamma$ was detected only after $12 \mathrm{hr}$ of culture (Fig. 4A). This pattern of cytokine production was consistent with the previous findings that showed the peak level of IL-4 production in normal NKT cells preceded the peak level of IFN- $\gamma$ production ${ }^{21}$. 2E10

A.
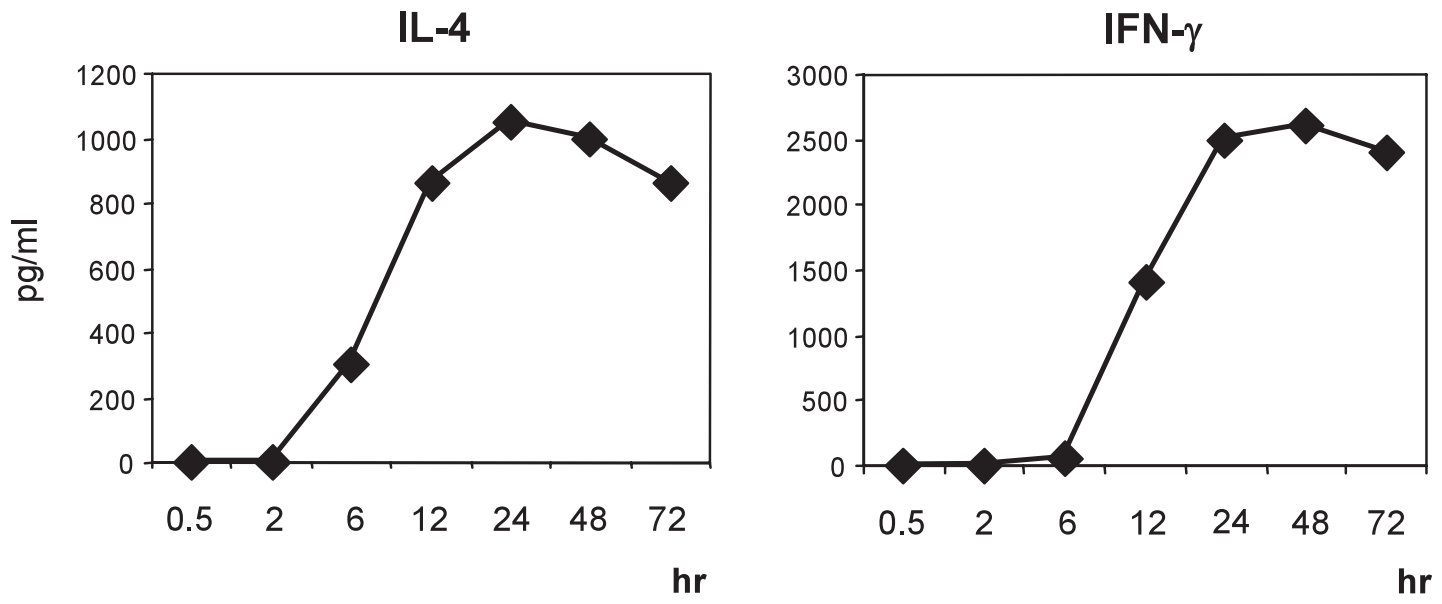

B.
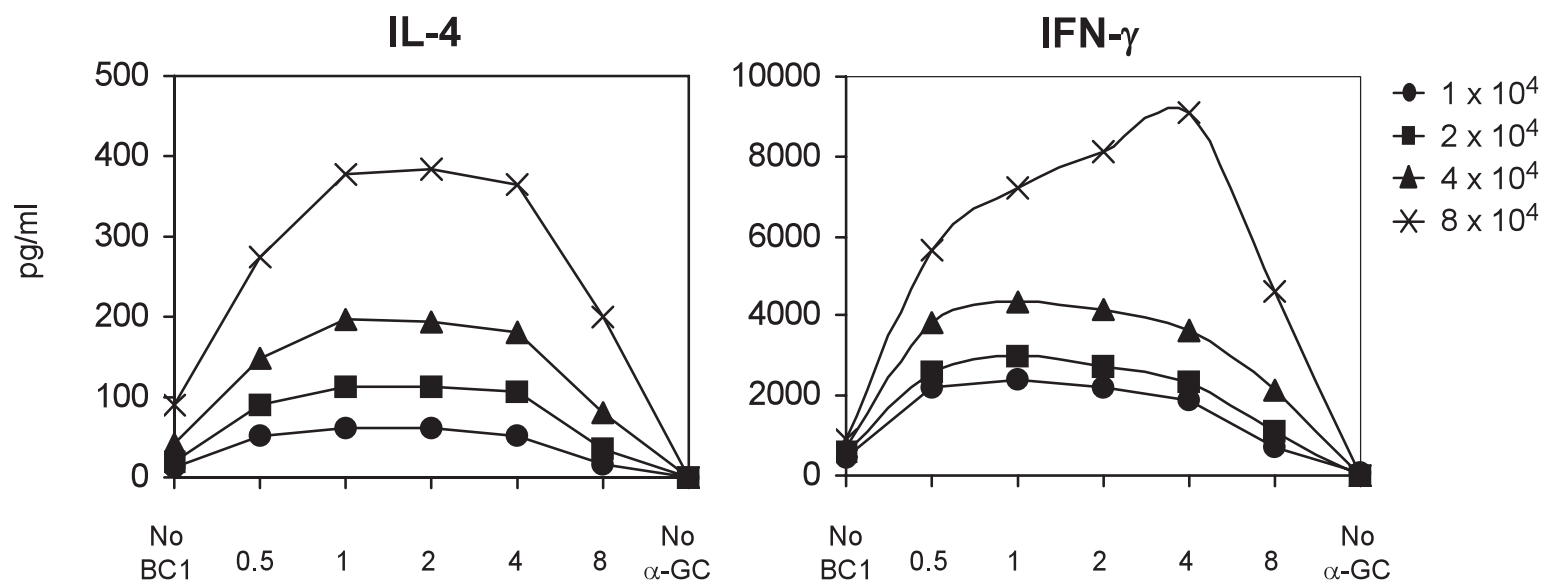

DC $\left(X_{10}\right)$

Fig. 4. IL- 4 and IFN- $\gamma$ production by $1 \mathrm{~B} 6$ and $2 \mathrm{E} 10$ cells. A. Time course of IL- 4 (left panel) and IFN- $\gamma$ (right panel) production by $1 \mathrm{~B} 6$ upon crosslinking with anti- $\mathrm{CD} 3 \mathrm{mAbs}$. Cytokines in the supernatant were quantified as described in the MATERIALS and METHODS section. B. The production of IL-4 (left panel) and IFN- $\gamma$ (right panel) by $2 \mathrm{E} 10$ cells stimulated with $a^{-G a l C e r}$ in the presence of the $\mathrm{BC} 1$ murine dendritic cell line. Different ratios of $2 \mathrm{E} 10$ and $\mathrm{BC} 1$ cells were cocultured. The symbols in the graph (right) represent the number of responder hybridoma cells in each culture, which ranged from $1 \times 10^{4}$ to $8 \times 10^{4}$. The numbers of $\mathrm{BC} 1$ cells varied between 0.5 $\times 10^{4}$ and $8 \times 10^{4}$ cells/ culture, whereas cultures lacking BC1 cells ( NoBC1) or $a^{-G a l C e r ~(N o ~} a$-GC) served as controls. Thus, the ratio of responder cells to $\mathrm{BC} 1$ cells varied from $16: 1$ to $1: 8$, not including the no- $\mathrm{BC} 1$ cell control culture. 
cells demonstrated similar kinetics for the production of these cytokines (data not shown).

When $2 \mathrm{E} 10$ cells and $\mathrm{BC} 1$ dendritic cells were cocultured at different cellular ratios (the ratios of hybridoma cells to $\mathrm{BC} 1$ cells were between $1: 8$ and $16: 1$ ), both the levels of IL-4 and IFN- $\gamma$ production were dependent on the number of hybridoma cells (Fig. 4B). It seemed that optimal cellular ratio (hybridoma cell number to $\mathrm{BCl}$ cell number) fell between 1 and 4 . Of note, 2E10 cells produced small but significant amounts of IL-4 and IFN- $\gamma$ even in the absence of $\mathrm{BC} 1$ cells, especially when the cellular density of the culture was high. This result suggests that CD1d expressed on 2E10 cells is directly involved in presenting the $a$-GalCer ligand (see Fig. 1B). 1B6 cells demonstrated the same reactivity (data not shown). Furthermore, IL-2 and TNF- $a$ were produced by $a$-GalCer-stimulated 1B6 cells (data not shown). Therefore, our system should be convenient and useful for screening compounds that directly act on NKT cells and modulate cytokine production in the absence of antigenpresenting cells.

The involvement of NKT cells in various diseases has been reported and the functional modulation of these cells can alter the development of these diseases ${ }^{3-6}$. For example, we have reported that NKT cells accelerate atherogenesis ${ }^{22}$ and are involved in the development of a murine model of autoimmune hepatitis ${ }^{23}$. Thus, it may be possible to treat these diseases by regulating certain functions of NKT cells. To this end, the stable NKT-cell hybridomas established in the present study, which retain essential characteristics of NKT cells, should help with future investigations, allowing the effects of inhibitors and modulators on the expression levels of genes involved in the immunological responses of NKT cells to be examined in vitro.

\section{ACKNOWLEDGMENTS}

We would like to thank Dr. Willi Born for the BW1100 cell line, Dr. Albert Bendelac for the RBL-CD1d cell line, Takeda Chemical Industries for rhIL-2, and Kirin Brewery Company for $a$-GalCer. This study was supported in part by a Grant-in-Aid for Scientific Research (S), (C), and Priority Areas, a Grant-in-Aid for Young Scientists (B) from the Ministry of Education, Culture, Sports, Science and Technology (MEXT), and grants from the Suhara Memorial Foundation and Heisei Ijuku Tomakomai East Hospital.

\section{REFERENCES}

1 Bendelac A, Rivera MN, Park SH, Roark JH : Mouse CD1specific NK1 T cells: development, specificity and function. Annu Rev Immunol 15 : 535-562, 1997

2 Godfrey DI, MacDonald HR, Kronenberg M, Smyth MJ, Van Kaer L : NKT cells: what's in a name? Nat Rev Immunol 4 :
231-237, 2004

3 Godfrey DI, Kronenberg M : Going both ways : immune regulation via CD1d-dependent NKT cells. J Clin Invest 114 : 1379- 1388, 2004

$4 \mathrm{Yu}$ KOA, Porcelli SA : The diverse function of CD1d-restricted NKT cells and their potential for immunotherapy. Immunol Lett $100:$ 42-55, 2005

5 Van Kaer L : $a$-galactosylceramide therapy for autoimmune diseases: prospects and obstacles. Nat Rev Immunol 5: 31-42, 2005

6 Miyake S, Yamamura T: Therapeutic potential of glycolipid ligands for natural killer (NK) T cells in the suppression of autoimmune diseases. Curr Drug Targets Immune Endocr Metabol Disord 5: 315-322, 2005

7 Lantz O, Bendelac A : An invariant T cell receptor $a$ chain is used by a unique subset of major histocompatibility complex class Ispecific $\mathrm{CD}^{+}$and $\mathrm{CD}^{-} 8^{-} \mathrm{T}$ cells in mice and humans. J Exp Med 180: 1097-1106, 1994

8 Cardell S, Tangri S, Chan S, Kronenberg M, Benoist C, Mathis D : CD1-restricted $\mathrm{CD}^{+} \mathrm{T}$ cells in major histocompatibility complex class II-deficient mice. J Exp Med 182 : 993-1004, 1995

9 Behar SM, Cardell S: Diverse CD1d-restricted T cells : diverse phenotypes, and diverse functions. Semin Immunol 12 : 551-560, 2000

10 White J, Blackman M, Bill J, Kappler J, Marrack P, Gold DP, Born W : Two better cell lines for making hybridomas expressing specific T cell receptors. J Immunol 143 : 1822- 1825, 1989

11 Iwabuchi K, Iwabuchi C, Tone S, Itoh D, Tosa N, Negishi I, Ogasawara K, Uede T, Onoé K: Defective development of NK1.1 $1^{+} \mathrm{T}$-cell antigen receptor $a \beta^{+}$cells in zeta-associated protein 70 null mice with an accumulation of $\mathrm{NK} 1.1^{+} \mathrm{CD}^{-}$NK-like cells in the thymus. Blood 97 : 1765-1775, 2001

12 Arase H, Arase-Fukushi N, Good RA, Onoé K: Lymphokineactivated killer cell activity of $\mathrm{CD} 4^{-} \mathrm{CD} 8^{-} \mathrm{TCR}_{a} \beta^{+}$thymocytes. J Immunol 151: 546-555, 1993

13 Harlow E, Lane D : Antibodies- A laboratory manual. New York, Cold Spring Harbor Laboratory, pp 139-237. 1988

14 Chomczynski P, Sacchi N : Single step method of RNA isolation by acid guanidium thiocyanate-phenol-choloroform extraction. Anal Biochem 162: 156-159, 1987

15 Itoh Y, Kajino K, Ogasawara K, Takahashi A, Namba K-I, Negishi I, Matsuki N, Iwabuchi K, Kakinuma M, Good RA, Onoé $\mathrm{K}$ : Interaction of pigeon cytochrome $c$-(43-58) peptide analogs with either $\mathrm{T}$ cell antigen receptor or $\mathrm{I}-\mathrm{A}^{\mathrm{b}}$ molecule. Proc Natl Acad Sci USA 94 : 12047-12052, 1997

16 Yanagawa Y, Iijima N, Iwabuchi K, Onoé K: Activation of extracellular signal-related kinase by TNF- $a$ controls the maturation and function of murine dendritic cells. J Leukoc Biol 71 : 125-132, 2002

17 Minami K, Yanagawa Y, Iwabuchi K, Shinohara N, Harabayashi $\mathrm{T}$, Nonomura $\mathrm{K}$, Onoé $\mathrm{K}$ : Negative feedback regulation of $\mathrm{T}$ helper type 1(Th1)/Th2 cytokine balance via dendritic cell and natural killer T cell interactions. Blood 106 : 1685-1693, 2005 


\section{Nyambayar $\mathrm{D}$, et al.}

18 Chen H, Huan H, Paul WE : NK1.1 $1^{+} \mathrm{CD} 4^{+} \mathrm{T}$ cells lose NK1.1 expression upon in vitro activation. J Immunol 158 : 5112-5119, 1997

19 Shimizu A, Sasaki H, Aoyagi K, Yoshida M, Kato K, Heike Y, Ikarashi Y, Shirakawa K, Takaue Y, Miyajima A, Terada M, Nagai H, Wakasugi $\mathrm{H}$ : The mouse natural killer T cellassociated antigen recognized by U5A2- 13 monoclonal antibody is intercellular adhesion molecule-1. Immunol Lett 92 : 227-235, 2004

20 Makino Y, Kanno R, Ito T, Higashino K, Taniguchi M: Predominant expression of invariant $\mathrm{V}_{a} 14^{+}$TCR $a$ chain in NK1.1 $1^{+} \mathrm{T}$ cell populations. Int Immunol 7 : 1157-1161, 1995

21 Miyamoto K, Miyake S, Yamamura T: A synthetic glycolipid prevents autoimmune encephalomyelitis by inducing TH2 bias of natural killer T cells. Nature 413: 531-534, 2001

22 Nakai Y, Iwabuchi K, Fujii S, Ishimori N, Watano K, Mishima T, Iwabuchi C, Tanaka S, Dashtsoodol N, Nakayama T, Taniguchi M, Miyake S, Yamamura T, Kitabatake A, Joyce S, Van Kaer L, Onoé K : Natural killer T cells accelerate atherogenesis in mice. Blood 104 : 2051-2059, 2004

23 Diao $\mathrm{H}$, Kon S, Iwabuchi K, Kimura C, Morimoto J, Ito D, Segawa T, Maeda M, Hamuro J, Nakayama T, Taniguchi M, Yagita H, Van Kaer L, Onoé K, Denhardt D, Rittling S, Uede T : Osteopontin as a mediator of NKT cell function in $\mathrm{T}$ cell mediated liver diseases. Immunity $21: 539-550,2004$ 